\author{
MiodRag B. MILENOVIĆ ${ }^{1}$ \\ NEBOJŠA M. MILIĆEVIĆ ${ }^{2}$ \\ UNIVERSITY OF NIŠ, FACULTY OF PHILOSOPHY \\ DEPARTMENT OF PSYCHOLOGY
}

MINA P. DIMITRIJEVIĆ3

HERMODS SFI, GÖTEBORG, SWEDEN

\title{
SLEEP QUALITY AND LIFE SATISFACTION OF RAILWAY EMPLOYEES
}

ABSTRACT. The aim of the study was to examine the relationship between sleep quality and life satisfaction. The basic hypothesis was that the dimensions of quality and quantity of sleep will be statistically significant predictors of life satisfaction among employees of the Serbian Railways. A total of 126 workers working in different jobs were surveyed: dispatcher, information worker, cashier, train driver, and conductor. Respondents differed according to gender, age, and years of service. The main research variables were operationalized by The Pittsburgh Sleep Quality Index (PSQI; Buysse et al., 1989) and the Satisfaction Life Scale (SWLS; Diener et al., 1985). The results showed that based on the regression model consisting of sleep quality modalities, the criterion variable - life satisfaction $\left(\mathrm{R}^{2}=.40, \mathrm{p}<0.01\right)$ can be statistically significantly explained. The largest individual contribution to the prediction of the criterion variable has the predictor of dysfunction during the day $(\beta=-.42, p<0.01)$, followed by sleep disorders $(\beta=-.22, p$ $<0.05)$ and sleep duration $(\beta=-.22, p<0.01)$. Examination of differences with respect to some sociodemographic variables showed that women show poorer quality of sleep, and that the quality of sleep decreases with age,

\footnotetext{
miograg.milenovic@filfak.ni.ac.rs

nebojsa.milicevic@filfak.ni.ac.rs

minadimitrijevic91@gmail.com
}

This paper was submitted on March $14^{\text {th }}, 2021$ and accepted for publication at the meeting of the Editorial Board held on November $16^{\text {th }}, 2011$. 
that more sleep disorders occur, which causes dysfunctions during the day and more frequent use of medications.

KEYWORDS: quality of sleep, life satisfaction, railway employees.

\section{INTRODUCTION}

The field of psychophysiology of work represents a fertile ground for research activities in professions related to the transport of people and goods. One of them, railway transport, has recently experienced a rapid development in our country due to the introduction of new technologies, which, on the other hand, requires employees in this complex system to increase their efforts in performing work duties. This effort, among other things, is reflected in psychophysiological functions, such as sleep. The sleep function, further, is a component of the causative agents that affect an individual's daily activities and essentially participates in what the psychological literature calls life satisfaction. Therefore, in this research we tried to examine this relationship, having in mind the type of jobs, which are performed in different shifts, in the railway transport system.

\section{QUALITY OF SLEEP}

Sleep quality is a generally accepted construct used in clinical psychology, although its operationalization is still questionable. Some of the papers dealing with the relationship between subjective and objective sleep do not find a correlation between subjective and objective indicators of sleep quality (Landry, Best, \& Liu-Ambrose, 2015). In psychology, sleep quality is usually approached using subjective assessment scales, while researchers in the medical sciences are more likely to focus on some of the objective indicators. Subjective indicators of sleep quality are mainly focused on qualitative indicators such as sleep length, drowsiness, feeling after sleep and the like. However, the quality of sleep, as found in various studies, may also depend on many individual factors, including the instruments we use (Bixler, Kales, A., Soldatos, Kales, J.D., \& Healey, 1979). The mechanism of alternating wakefulness and sleep can be disrupted for a variety of reasons and cause a number of problems. sleep disorders can be divided into those caused by disrespect of circadian rhythms, inorganic factors, as well as those that accompany certain psychiatric and neurological dysfunctions. In the first 
case, the natural rhythm of wakefulness and sleep, which changes within a 24-hour period, can be disturbed for several reasons. Modern way of life, later going to sleep of a modern man and shortening the rest period, working in the third shift, rotation of shifts, stress, etc. act to shift the rhythm of human physiological functions. The entire duration, continuity and integrity of sleep are disturbed. The most important changes in this regard are irregular, insufficient and intermittent sleep (Obrenović, 2003).

\section{SLEEP QUALITY AND SHIFT WORK}

The quality of sleep is one of the most important conditions for efficient work in shift work. Petz and Vidaček (2000) mention, among others, the dimension of distinguishing between morning and evening types as predictors of sleep quality. Morning types are considered to be people who get up about two hours earlier than the majority of the population (so-called indifferent types) and are ready to sleep between 20.00 and 22.00 , unlike evening types who wake up about two hours later than most of the population and go to sleep between midnight and 2 a.m. (Horne \& Ostberg, 1976). Morning types have a more rigid circadian rhythm, but when it comes to adjusting to a new shift schedule, research shows that evening types are more adaptable in this regard (Farbos, Bourgeois-Bougrine, Cabon, Mollard, \& Coblentz, 2000). However, bearing in mind that aging leads to less evening and more morning types with age, from the aspect of age this dimension is of great importance for workers working in different shifts (Cavallera \& Giudici, 2008). Night work is not in accordance with biological mechanisms, such as the circadian rhythm, so night shifts can impair the quality of daily functioning. The total sleep time for 24 hours was reduced the most after the first night spent at work. On other days, sleep time is gradually extended, but the deficit always remains. It was calculated that even after three weeks of uninterrupted work in the night shift, the average length of sleep, calculated for every 24 hours, is always less than that these same workers worked normally during the day and slept at night. When working in a daily shift, the average length of a worker's sleep for a 24-hour period is about 8 hours. The same population of workers, when working in the night shift, shortens the average sleep time to about 7 hours. Thus, the total amount of sleep in a week with night work is significantly less than when individual works in other shifts. The total sleep deficit is greatest in the first days after moving to a new 
shift, and then progressively decreases. In younger people, the initial adaptation to phase inversion is achieved only on the sixth or seventh night. Older people reach the initial phase of adaptation more slowly, even the phase of readaptation, and the reason for that is the more rigid structure of their circadian rhythm and more inert mechanisms of regulation of physiological variables. Only after 10 to 12 consecutive nights of work, the habituation is more complete, and after 20-30 days it is stabilized. Therefore, those who work permanently at night do not suffer from chronic insomnia, or are resistant to it. In addition, shift rotation causes numerous changes in other psychophysiological functions. The question arises of the existence of effective mechanisms that can reduce the workload, ie increase work efficiency and improve the quality of life. A large number of studies have addressed this problem and some of the solutions may be to increase the light intensity during night work or to darken the sleeping area during the day (Baehr, Fogg, and Eastman, 1999). Some say that a study in which workers were allowed to sleep for a maximum of one hour during night shifts, between 23.30 and 03.30 (Takeyama, Itani, Tachi, Sakamura, \& Suzumura, 2002), achieved good results in this field.

\section{SLEEP QUALITY IN RAILWAY WORKERS AND SHIFT WORK}

Railway workers have somewhat more specific working circumstances than other employees in the transport industry. In one study, the results show that the subjective load on drivers is high (Ingre, Söderström, Kecklund, Åkerstedt, and Kecklund, 2000) in large part due to feelings of monotony. Drivers are usually alone in their cabs, and while driving they are usually focused on speed and movement (Branton 1979), but also on controlling various dynamic forces, upcoming terrain, traffic signs and communication. Rail shifts are usually irregularly timed, starting in the early morning hours, with often short distance between them (Hak \& Kampman 1981; Ingre et al., 2000; Torsvall, Åkerstedt, \& Gillberg, 1981), while sleep conditions can be very unfavorable, resulting in poor rest (Hak \& Kampman 1981; Ingre et al., 2000). Such conditions can lead to drowsiness during work. The development infrastructure of the railway and its functionality can also be a very important factor, because slow railways and less extensive transport lead to greater monotony in work and a higher risk of drowsiness. One study conducted on railway workers in Greece (Härmä, Sallinen, Ranta, Mutanen, \& Müller, 2002) suggests that adjusting shift work, length, and 
rest time, in addition to extending the main sleep period, would likely reduce employee drowsiness.

\section{LIFE SATISFACTION}

Life satisfaction is one of the relatively recent constructs of positive psychology, which refers to the global evaluation of personal life (Penezić, 2006) and is a component of subjective well-being. The development of positive psychology is primarily associated with one of the dominant psychological directions - the so-called humanistic psychology (Diener, Oishi, \& Lucas, 2003), although other psychological directions are also interested in factors of optimal functioning and adjustment of the individual. Life satisfaction, however, like other concepts of positive psychology, is difficult to define. According to one of the definitions, it represents a complete perception and evaluation of one's own life and is most often described as a cognitive component of subjective well-being (Diener, 2000). However, precisely because of insufficient knowledge of this concept, the expansion of life satisfaction research is noticeable (Arslan, Hamarta, \& Uslu, 2010; Diener \& Diener, 2009), using in such research a variety of methods. Positive psychology grows out of critiques aimed at the fact that psychological interests and research have mainly focused on the negative aspects of the overall continuum of individual functioning, based on the paradigm of "neopositivism" (Lucas \& Diener, 2010).

In order to better understand the concept of life satisfaction, it is necessary to get to know its broader background, the basic concept of positive psychology - subjective well-being (or, colloquially, the experience of happiness). In recent years, a model consisting of two components has been predominantly used (Diener et al., 2003; Lucas \& Diener, 2010): cognitive, i.e. cognitive, and affective (Diener et al., 1985; Pavot \& Diener, 1993). The affective component of well-being was originally understood as a kind of balance of positive and negative affectivity (Diener et al., 1985; Pavot \& Diener, 1993). Later, mainly due to the accumulation of empirical findings, this component was defined as a more or less pronounced dominance of positive over negative affectivity (Diener et al., 2003; Lucas \& Diener, 2010). The cognitive component is the experience or (self) assessment of the individual to what extent he is satisfied with his own life in general, in all its aspects, regardless of specific values, norms and goals (Diener et al., 1985; Pavot \& Diener, 1993). Life satisfaction is, as we see, a cognitive component of well-being, refer- 
ring to a personal assessment of well-being and happiness, and is the most commonly used indicator of well-being and quality of life.

\section{METHOD}

\section{SUBJECT OF RESEARCH}

With this research, we tried to shed light on the relationship between sleep quality (represented by indicators: subjective sleep quality, sleep latency, sleep duration, sleep efficiency, sleep disorders, use of hypnotics and dysfunction during the day) and life satisfaction.

\section{SAMPLE}

Sample was consisted of 126 respondents, both sexes ( 83 men and 43 women), different ages ( 31 to 62 ) and work experience ( 8 to 41 years).

\section{INSTRUMENTS}

For this purpose, two instruments were used:

1) The Pittsburgh Sleep Quality Index - PSQI (Buysse et al., 1989) which assesses the overall quality of sleep in patients in clinical studies.

2) Satisfaction Life Scale-SLS (Diener, Emmons, Larsen, \& Griffin, 1985) which assesses the cognitive component of subjective well-being.

RESULTS

\section{DESCRIPTIVE PARAMETERS}

On the Life Satisfaction Scale, the possible range of scores goes from 5 to 35 , with a score of 20 representing the neutral point of the scale. Low scores, between 5 and 9, reflect extreme dissatisfaction with life while scores between 31 and 35 are indicators of extreme satisfaction (Pavot \& Diener, 2008). The average score obtained empirically on this sample is 18.94 (with a standard deviation of SD $=5.84$ ), which is below the neutral point of the scale, and corresponds to a slight dissatisfaction with life (Table 1). 


\begin{tabular}{|c|r|r|r|r|r|r|}
\hline & \multicolumn{1}{|c|}{$\mathrm{N}$} & \multicolumn{1}{c|}{ MIN } & \multicolumn{1}{c|}{ MAX } & \multicolumn{1}{c|}{ M } & \multicolumn{1}{c|}{ SE } & \multicolumn{1}{c|}{ SD } \\
\hline LIFE SATISFACTION & 126 & 8.00 & 31.00 & 18.94 & .52 & 5.84 \\
\hline SLEEP QUALITY & 126 & .00 & 3.00 & 1.23 & .07 & .82 \\
\hline SLEEP LATENCY & 125 & .00 & 3.00 & 1.28 & .08 & .94 \\
\hline DURATION OF SLEEP & 126 & .00 & 3.00 & 1.24 & .07 & .80 \\
\hline SLEEP EFFICIENCY & 126 & .00 & 3.00 & .55 & .08 & .92 \\
\hline SLEEP DISORDERS & 126 & .00 & 3.00 & 1.49 & .05 & .61 \\
\hline DYSFUNCTION DURING THE DAY & 126 & .00 & 3.00 & 1.25 & .07 & .83 \\
\hline USE OF DRUGS & 126 & .00 & 3.00 & 1.21 & .07 & .86 \\
\hline \hline
\end{tabular}

TABLE 1: PRESENTATION OF DESCRIPTIVE STATISTICAL INDICATORS ON THE EXAMINED VARIABLES

[TABELA 1. DESKRIPTIVNI PODACI INDIKATORA ISTRAŽIVANIH VARIJABLI]

The range of scores on the Scale for measuring sleep quality goes from 0 to 3, with higher scores indicating poorer sleep quality. The results indicate that the worst estimated dimension is sleep disorders $(\mathrm{AS}=1.49, \mathrm{SD}=.61)$, and the best sleep efficiency $(\mathrm{M}=.55, \mathrm{SD}=$ 0.92). These values are not compared with the reference sample, so at this point we can only give a description of the distribution of results on a specific sample.

\section{INFERENTIAL STATISTICS}

\begin{tabular}{|c|c|c|}
\hline & & LIFE SATISFACTION \\
\hline \multirow{3}{*}{ SLEeP Quality } & $r$ & $-.439^{* *}$ \\
\hline & $\mathrm{p}$ & .000 \\
\hline & $\mathrm{N}$ & 126 \\
\hline \multirow{3}{*}{ SLEEP LATENCY } & $r$ & $-.343^{* *}$ \\
\hline & $\mathrm{p}$ & .000 \\
\hline & $\mathrm{N}$ & 125 \\
\hline \multirow{3}{*}{ DURATION OF SLEEP } & $r$ & $-.280^{* *}$ \\
\hline & $\mathrm{p}$ & .002 \\
\hline & $\mathrm{N}$ & 126 \\
\hline
\end{tabular}

TABLE 2: EXAMINING THE CORRELATION OF BASIC RESEARCH VARIABLES [TABELA 2. ISPITIVANJE KORELACIJA OSNOVNIH ISTRAŽIVAČKIH VARIJABLI]

Miodrag B. Milenović, NebojŠA M. MilićEvić, Mina P. DiMitrijeVić9 
Collection of Papers of the Faculty of Philosophy LI(3)/2021

\begin{tabular}{|c|c|c|}
\hline \multirow{3}{*}{ SLEEP EFFICIENCY } & $\mathrm{r}$ & -.091 \\
\cline { 2 - 3 } & $\mathrm{p}$ & .309 \\
\cline { 2 - 3 } & $\mathrm{p}$ & 126 \\
\hline \multirow{3}{*}{ SLEEP DISORDERS } & $\mathrm{r}$ & $-.201^{*}$ \\
\cline { 2 - 3 } & $\mathrm{p}$ & .024 \\
\cline { 2 - 3 } & $\mathrm{N}$ & 126 \\
\hline \multirow{3}{*}{ DYSFUNCTION DURING THE DAY } & $\mathrm{r}$ & $-.518^{* *}$ \\
\cline { 2 - 3 } & $\mathrm{p}$ & .000 \\
\cline { 2 - 3 } & $\mathrm{N}$ & 126 \\
\hline \multirow{2}{*}{ USE OF DRUGS } & $\mathrm{r}$ &.$- .477^{* *}$ \\
\cline { 2 - 3 } & $\mathrm{p}$ & .000 \\
\cline { 2 - 3 } & $\mathrm{N}$ & 126 \\
\hline \hline
\end{tabular}

TABLE 2: EXAMINING THE CORRELATION OF BASIC RESEARCH VARIABLES [TABELA 2. ISPITIVANJE KORELACIJA OSNOVNIH ISTRAŽIVAČKIH VARIJABLI]

Based on the correlation coefficients, it can be concluded that, in general, poorer sleep quality (higher values on sleep quality dimensions) is associated with lower life satisfaction (Table 2).

The results shown in Table 3 show that the regression model consisted of the dimensions of sleep quality statistically significantly explains $39.9 \%$ of the variance of life satisfaction $\left(\mathrm{R}^{2}=.399, \mathrm{p}<0.01\right)$. The multiple correlation coefficient indicates a high correlation between the model and the criteria. The following table will show the individual contributions of certain dimensions.

\begin{tabular}{|c|c|c|c|c|}
\hline Model & $\mathrm{R}$ & $\mathrm{R}^{2}$ & Adjusted $\mathrm{R}^{2}$ & Sig. \\
\hline 1 & .632 & .399 & .363 & .000 \\
\hline \hline
\end{tabular}

TABLE 3: REGRESSION MODEL: SLEEP QUALITY DIMENSIONS AS PREDICTORS OF LIFE SATISFACTION [TABELA 3. REGRESIONI MODEL DIMENZIJA KVALITETA SPAVANJA KAO PREDIKTORA ZADOVOLJSTVA ŽIVOTOM]

Of the predictors that make up the examined regression model, the predictor dysfunction during the day $(\beta=-.42, \mathrm{p}<0.01)$, then sleep disorders $(\beta=-.22, p<0.05)$ and sleep duration have the largest individual contribution to the prediction of the criterion variable life satisfaction. $(\beta=-.22, p<0.01)$. The negative correlation between these variables leads to the conclusion that poorer quality of 
sleep, i.e. the presence of dysfunction during the day, sleep disorders and shorter sleep duration are associated with lower life satisfaction (Table 4).

\begin{tabular}{|c|r|r|}
\hline MODEL & \multicolumn{1}{|c|}{ Beta } & \multicolumn{1}{c|}{$\mathrm{p}$} \\
\hline SLEEP QUALITY & -.148 & .182 \\
\hline SLEEP LATENCY & -.138 & .128 \\
\hline DURATION OF SLEEP & -.217 & .007 \\
\hline SLEEP EFFICIENCY & .061 & .448 \\
\hline SLEEP DISORDERS & -.223 & .019 \\
\hline DYSFUNCTION DURING THE DAY & -.424 & .000 \\
\hline USE OF DRUGS & -.119 & .263 \\
\hline \hline
\end{tabular}

TABLE 4: REgRESSION COEFFICIENTS [TABELA 4. REGRESIONI KOEFICIJENTI]

Based on the results of the applied $t$ test to examine the differences between groups, it can be concluded that there are statistically significant differences in the expression of sleep quality $(t=-3.099, p<0.01)$, sleep latency $(t=-3.524, p<0.01)$, sleep disorders $(\mathrm{t}=-3.445, \mathrm{p}<0.01)$ and dysfunction during the day $(\mathrm{t}=-2.813, \mathrm{p}<0.01)$ with respect to the sex of the subjects (Table 5).

\begin{tabular}{|c|c|c|c|}
\hline & $\mathrm{t}$ & $\mathrm{df}$ & Sig. \\
\hline SLEEP QUALITY & $\mathbf{- 3 . 0 9 9}$ & 124 & $\mathbf{. 0 0 2}$ \\
\hline SLEEP LATENCY & $\mathbf{- 3 . 5 2 4}$ & 123 & $\mathbf{. 0 0 1}$ \\
\hline DURATION OF SLEEP & .755 & 124 & .452 \\
\hline SLEEP EFFICIENCY & .520 & 124 & .604 \\
\hline SLEEP DISORDERS & $\mathbf{- 3 . 4 4 5}$ & 124 & $\mathbf{. 0 0 1}$ \\
\hline DYSFUNCTION DURING THE DAY & $\mathbf{- 2 . 8 1 3}$ & 124 & $\mathbf{. 0 0 6}$ \\
\hline USE OF DRUGS & -1.565 & 124 & .120 \\
\hline LIFE SATISFACTION & 1.573 & 124 & .118 \\
\hline \hline
\end{tabular}

TABLE 5: EXAMINATION OF GENDER DIFFERENCES IN THE EXPRESSION OF SLEEP QUALITY DIMENSIONS AND LIFE SATISFACTION [TABELA 5. ISPITIVANJE RODNIH RAZLIKA U IZRAŽENOSTI DIMENZIJA KVALITETA SNA I ZADOVOLJSTVA ŽIVOTOM]

According to the results, it can be concluded that the quality of sleep decreases with age $(r=.230, p<0.01)$, that more sleep disor- 
ders occur $(\mathrm{r}=.186, \mathrm{p}<0.05)$, and dysfunction occurs during the day $(\mathrm{r}=.224, \mathrm{p}<0.05)$ and more frequent use of drugs $(\mathrm{r}=.338, \mathrm{p}<0.01)$.

\begin{tabular}{|c|c|c|}
\hline & & Age \\
\hline \multirow{3}{*}{ SLEEP QUALITY } & $\mathrm{r}$ & $.230^{* *}$ \\
\hline & $\mathrm{p}$ & .010 \\
\hline & $\mathrm{N}$ & 126 \\
\hline \multirow{3}{*}{ SLEEP LATENCY } & $\mathrm{r}$ & .042 \\
\hline & $\mathrm{p}$ & .639 \\
\hline & $\mathrm{N}$ & 125 \\
\hline \multirow{3}{*}{ DURATION OF SLEEP } & $\mathrm{r}$ & .041 \\
\hline & $\mathrm{p}$ & .648 \\
\hline & $\mathrm{N}$ & 126 \\
\hline \multirow{3}{*}{ SLEEP EFFICIENCY } & $\mathrm{r}$ & -.135 \\
\hline & $\mathrm{p}$ & .132 \\
\hline & $\mathrm{N}$ & 126 \\
\hline \multirow{3}{*}{ SLEEP DISORDERS } & $\mathrm{r}$ & $.186^{*}$ \\
\hline & $\mathrm{p}$ & .037 \\
\hline & $\mathrm{N}$ & 126 \\
\hline \multirow{3}{*}{ DYSFUNCTION DURING THE DAY } & $\mathrm{r}$ & $.224^{*}$ \\
\hline & $\mathrm{p}$ & .012 \\
\hline & $\mathrm{N}$ & 126 \\
\hline \multirow{3}{*}{ USE OF DRUGS } & $\mathrm{r}$ & $.338^{* *}$ \\
\hline & $\mathrm{p}$ & .000 \\
\hline & $\mathrm{N}$ & 126 \\
\hline
\end{tabular}

TABLE 6: CoRRELATION BETWEEN SLEEP QUALITY AND AGE [TABELA 6. KORELACIJE IZMEĐU KVALITETA SPAVANJA I STAROSTI]

Based on Pearson's correlation coefficients shown in the table, it can be concluded that there is no statistically significant correlation between sleep quality and work experience (Table 7.).

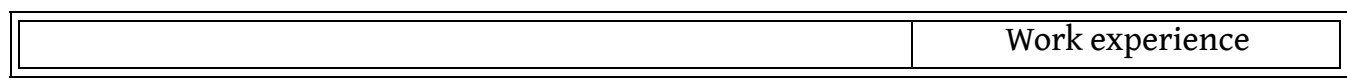

TABLE 7: CORRELATION BETWEEN SLEEP QUALITY AND WORK EXPERIENCE [TABELA 7. KORELACIJE IZMEĐU KVALITETA SPAVANJA I RADNOG ISKUSTVA] 
SLEEP QUALITY AND LIFE SATISFACTION OF RAILWAY EMPLOYEES

\begin{tabular}{|c|c|c|}
\hline \multirow{3}{*}{ SLEEP QUALITY } & $\mathrm{r}$ & .031 \\
\hline & $\mathrm{p}$ & .728 \\
\hline & $\mathrm{N}$ & 126 \\
\hline \multirow{3}{*}{ SLEEP LATENCY } & $\mathrm{r}$ & -.086 \\
\hline & $\mathrm{p}$ & .338 \\
\hline & $\mathrm{N}$ & 125 \\
\hline \multirow{3}{*}{ DURATION OF SLEEP } & $\mathrm{r}$ & .005 \\
\hline & $\mathrm{p}$ & .952 \\
\hline & $\mathrm{N}$ & 126 \\
\hline \multirow{3}{*}{ SLEEP EFFICIENCY } & $\mathrm{r}$ & -.107 \\
\hline & $\mathrm{p}$ & .231 \\
\hline & $\mathrm{N}$ & 126 \\
\hline \multirow{3}{*}{ SLEEP DISORDERS } & $\mathrm{r}$ & .025 \\
\hline & $\mathrm{p}$ & .784 \\
\hline & $\mathrm{N}$ & 126 \\
\hline \multirow{3}{*}{ DYSFUNCTION DURING THE DAY } & $\mathrm{r}$ & .029 \\
\hline & $\mathrm{p}$ & .743 \\
\hline & $\mathrm{N}$ & 126 \\
\hline \multirow{3}{*}{ USE OF DRUGS } & $\mathrm{r}$ & .167 \\
\hline & $\mathrm{p}$ & .061 \\
\hline & $\mathrm{N}$ & 126 \\
\hline
\end{tabular}

TABLE 7: CORRELATION BETWEEN SLEEP QUALITY AND WORK EXPERIENCE [TABELA 7. KORELACIJE IZMEĐU KVALITETA SPAVANJA I RADNOG ISKUSTVA]

\section{DISCUSSION AND CONCLUSION}

Railway workers have somewhat more specific working circumstances than employees in road and air transport. Drivers, for example, are usually alone in their cabs, and while driving they are usually focused on speed and movement (Branton 1979), but also on controlling various dynamic forces, upcoming terrain, traffic signs and communication. Shifts on the railway are usually of an irregular schedule, starting in the early morning hours and, often, the distance between them is very short (Hak \& Kampman 1981; Ingre et al., 2000). Sleep conditions can also be very unfavorable, and rest of 
poor quality (Hak \& Kampman 1981; Ingre et al., 2000). Such conditions can lead to drowsiness during work. Railway development infrastructure and its functionality can, in themselves, be a disruptive factor for efficient operation. Thus, for example, the relatively necessary slowness of large transports of goods (oil, agricultural products) causes monotony in work, and thus the risk of drowsiness in the executor of work. The following discussion of the results, in large part, confirms the findings obtained from employees of foreign railways.

The results showed that the regression model that makes up the dimensions of sleep quality statistically significantly explains $39.49 \%$ of the variance of the criterion variable life satisfaction. The multiple correlation coefficient indicates a high correlation between the model and the criteria. Of the predictors that make up the examined regression model, the greatest individual contribution to the prediction of the criterion variable life satisfaction has the predictor of dysfunction during the day, followed by sleep disorders and sleep duration. The negative correlation between these variables leads to the conclusion that poorer quality of sleep, ie the presence of dysfunction during the day, sleep disorders and shorter sleep duration are associated with lower life satisfaction.

To examine sociodemographic factors, we used t-test (gender, and work experience). It was obtained, first of all, that men and women differ with regard to the expression of the basic research variables. It was found that there are statistically significant differences in the expression of sleep quality, sleep latency, sleep disorders and dysfunction during the day. The results suggest that in all dimensions where there are statistically significant differences. Women achieve higher results, which indicates a poorer quality of sleep for the females. There are many studies that show a higher rate of sleep problems in women (Zhang \& Wing, 2006). Different explanations of these differences can be given. First, the higher prevalence of affective disorders in women compared to men (Arber, Bote, \& Meadows, 2009). Some other research refers to biological differences in sleep physiology between the sexes (Lindberg, Janson, Gislason, Bjornsson, Hetta, and Boman, 1997). The results of a study conducted in the Netherlands on the general population older than 50 years showed that women have a significantly poorer quality of sleep, they need more time when falling asleep and use sedatives more often, compared to men. In addition, women have disorders related to the onset and maintenance of sleep (Mid- 
delkoop, Smilde-van den Doel, Neven, Kamphuisen, \& Springer, 1996). In terms of sleep quality and age, our results coincide with the aforementioned Dutch study, which showed that the number of nocturnal awakenings increased significantly with age, in a subsample of men. Our findings represent an extension of epidemiological studies in the general population that suggest that sleep disorders are common in the elderly population, by linking reduced sleep quality to dysfunction during the day and more frequent use of medications.

What is a bit surprising is that there was no connection between the quality of sleep and the work experience, having in mind that the length of work experience is in proportion to the age of life. We found the explanation for such a result in the distribution of work experience in the sample was not normal, so the differences between subjects could not be detected. The comparison of groups was also made with regard to the expression of life satisfaction. There were no statistically significant differences, when it comes to life satisfaction, which indicates that, when it comes to railway employees, some more basic factors are related to basic psychophysiological functions, such as sleep quality, have priority in the self-perception of railway employees in terms of satisfaction with their own lives.

REFERENCES Arber, S., Bote, M., Meadows, R. (2009). Gender and socio-economic patterning of self-reported sleep problems in Britain. Soc Sci Med, 68, 281-289.

Arslan, C., Hamarta, E., Uslu, M. (2010). The relationship between conflict communication, self-esteem and life satisfaction in university students. Educational Research and Reviews, 5 (1), 31-34.

Baehr, E. K., Fogg, L. F., Eastman, Ch. I. (1999) Intermittent bright light and exercise to entrain human circadian rhythms to night work. Regulatory and integrative physiology, 277 (6), 1598-1604. https://doi.org/10.1152/ ajpregu.1999.277.6.R1598

Branton, P. (1979). Investigations into the skills of train-driving. Ergonomics, 22 (2), 155-164.

Bixler, E. O, Kales, A., Soldatos, C. R., Kales, J. D., Healey, S. (1979). Prevalence of sleep disorders in the Los Angeles metropolitan area. The American Journal of Psychiatry, 136 (10), 1257-1262. https://doi.org/10.1176/ ajp.136.10.1257

Buysse, D. J., Reynolds, C. F., Monk, T. H., Berman, S. R., Kupfer, D. J. (1989). The Pittsburgh Sleep Quality Index: a new instrument for psychiatric practice and research. Psychiatry research, 28 (2), 193-213. 
Cavallera, G. M. \& Giudici, S. (2008). Morningness and eveningness personality: A survey in literature from 1995 up till 2006. Personality and Individual differences, 44 (1), 3-21.

Diener, E. \& Diener, M. (2009). Cross-cultural correlates of life satisfaction and self-esteem. In: Culture and well-being (71-91). Springer Netherlands.

Diener, E. (2000). Subjective well-being: The science of happiness and a proposal for a national index. American psychologist, 55 (1), 34.

Diener, E., Emmons, R. A., Larsen, R. J., Griffin, S. (1985). The Satisfaction With Life Scale. Journal of Personality Assessment, 49, 71-75.

Diener, L., Oishi, S., Lucas, R. E. (2003). Personality, culture, and subjective well-being: Emotional and cognitive evaluations of life. Annual Review of Psychology, 54, 403-425.

Farbos, B., Bourgeois-Bougrine, S., Cabon, P., Mollard, R., Coblentz, A. (2000). Sleepiness during night-shift-sleeping habits or melatonin rhythm? A laboratory study. International journal of industrial ergonomics, 25 (3), 283-294.

Hak, A. \& Kampman, R. (1981). Working irregular hours: Complaints and state of fitness of railway personnel. In: A. Reinberg, N. Vieux, P. Andlauer (Eds.), Night and Shift Work: Biological and Social Aspects (229-236). Pergamon Press, Oxford.

Härmä, M., Sallinen, M., Ranta, R., Mutanen, P., Müller, K. (2002). The effect of an irregular shift system on sleepiness at work in train drivers and railway traffic controllers. Journal of sleep research, 11 (2), 141-151.

Horne, J. A. \& Ostberg, O. (1976). A self-assessment questionnaire to determine morningness-eveningness. Human circadian rhythms. International journal of chronobiology, 4 (2), 97-110.

Ingre, M., Söderström, M., Kecklund, G., Åkerstedt, T., Kecklund, L. (2000) Train drivers work situation. Working hours, sleep, stress and safety. Stress Research Report no. 292. Institutet för Psykosocial Medicine (IPM), Stockholm.

Landry, G. J., Best, J. R., Liu-Ambrose, T. (2015). Measuring sleep quality in older adults: a comparison using subjective and objective methods. Frontiers in aging neuroscience, $7,166$.

https://doi.org/10.3389/fnagi.2015.00166

Lindberg, E., Janson, C., Gislason, T., Bjornsson, E., Hetta, J., Boman, G. (1997). Sleep disturbances in a young adult population: can gender differences be explained by differences in psychological status? Sleep, 20, 381387.

Lucas, R. E. \& Diener, E. (2010). Subjective well-being. In: M. Lewis, J. M. Haviland-Jones, L. Feldman Barrett (Eds.), Handbook of emotions (471-484). New York: The Guilford Press. 
Middelkoop, H. A. M., Smilde-van den Doel, D. A., Knuistingh Neven, A., A. C. Kamphuisen, H. A .C., Springer, C. P. (1996). Subjective Sleep Characteristics of 1,485 Males and Females Aged 50-93: Effects of Sex and Age, and Factors Related to Self-Evaluated Quality of Sleep. The Journals of Gerontology: Series A, 51, (3), 108-115.

Pavot, W. G. \& Diener, E. (1993). Review of the Satisfaction With Life Scale. Psychological Assessment, 5, 164-172.

Petz, B. \& Vidaček, S. (2000). Istraživanja psihofizioloških i temporalnih uvjeta rada. Arhiv za higijenu rada i toksikologiju, 50 (4), 405-421

Penezić, Z. (2006). Zadovoljstvo životom u adolescentnoj i odrasloj dobi. Društvena istraživanja, 15 (4-5), 643-669.

Takeyama, H., Itani, T., Tachi, N., Sakamura, O., Suzumura, H. (2002). Psycho-physiological effects of naps during night shifts on morning types and evening types. Journal of Occupational Health, 44 (2), 89-98.

Torsvall, L., Åkerstedt, T., Gillberg, M. (1981). Age, sleep and irregular workhours: a field study with electroencephalographic recordings, catecholamine excretion and self-ratings. Scandinavian journal of work, environment \& health, 7, 196-203.

Zhang, B. \& Wing, Y. K. (2006). Sex differences in insomnia: a meta-analysis. Sleep, 29, 85-93.

\section{МИОДРАГ Б. МИЛЕНОВИЋ \\ НЕБОЈША М. МИЛИЋЕВИЋ \\ УНИВЕРЗИТЕТ У НИШУ, ФИЛОЗОФСКИ ФАКУЛТЕТ \\ ДЕПАРТМАН ЗА ПСИХОЛОГИЈУ}

МИНА П. ДИМИТРИЈЕВИЋ

ХЕРМОНДС СФИ, ГЕТЕБОРГ, ШВЕДСКА

РЕЗИМЕ

КВАЛИТЕТ СПАВАњА И ЗАДОВОљСТВО ЖИВОТОМ

ЗАПОСЛЕНИХ НА ЖЕЛЕЗНИЦИ

Циљ спроведеног истраживања био је да се испитају односи између квалитета спавања и задовољства животом. Основна хипотеза била је да ће димензије квалитета и квантитета спавања бити статистички значајни предиктори задовољства животом, код запослених на Железници Србије. Испитано је укупно 126 радника који раде на различитим радним местима: диспечер, радник на информацијама, благајник, машиновођа и кондуктер. Испитаници су се разликовали према полу, годинама старости и годинама радног стажа. Основне варијабле истраживања опе- 
рационализоване су Питсбуршким индексом квалитета спавања (The Pittsburgh Sleep Quality Index - PSQI; Buysse et al., 1989) и Скалом задовољства животом (Satisfaction Life Scale - SWLS; Diener et al., 1985). Резултати су показали да се на основу регресионог модела који чине модалитети квалитета спавања могу статистички значајно објаснити: критеријумска варијабла - задовољство животом $\left(\mathrm{R}^{2}=.40, \mathrm{p}<0.01\right)$. Највећи појединачни допринос предикцији критеријумске варијабле има предиктор дисфункционалност у току дана $(\beta=-.42, p<0.01)$, затим поремећаји спавања $(\beta=-.22, \mathrm{p}<0.05)$ и трајање сна $(\beta=-.22, \mathrm{p}<0.01)$. Испитивање разлика с обзиром на неке социодемографске варијабле показало је да жене показују лошији квалитет спавања, а да годинама опада квалитет сна, да се јавља више поремећаја спавања, што узрокује дисфункционалност у току дана и чешћу употребу лекова.

КључНЕ РЕчИ: квалитет спавања; задовољство животом; запослени на железници.

Овај чланак је објављен и дистрибуира се под лиценцом Creative Commons Ауторство-Некомерцијално Међународна 4.0 (CC BY-NC 4.0 | https://creativecommons.org/licenses/by-nc/4.0/). This paper is published and distributed under the terms and conditions of the Creative Commons Attribution-NonCommercial International 4.0 licence (CC BY-NC 4.0 | https://creativecommons.org/licenses/by-nc/4.0/). 